\title{
Studies on the Oxidative Metabolism of Carbohydrate in Diabetics
}

I. Metabolism of $\alpha$-keto acids in Patients with Diabetes Mellitus

$$
\text { By }
$$

\section{Yukio SHIGETA}

From the 1st Department of Internal Medicine, Osaka University, Medical School

(Director : Prof. Dr. T. Yoshida)

It is well known that the endocrine imbalance in diabetes mellitus causes metabolic disturbances not only of carbohydrate, but also of protein and lipids. However, in the treatment of diabetic patients, the importance of hyperglycemia and glycosuria as therapeutic guide has been too much emphasized, so that other metabolic abnormalities have often been neglected.

In order to control these patients more satisfactorily, the metabolism of $\alpha$-keto acids and the activity to acetylate para-aminobenzoic acid (PABA) were studied in patients with diabetes mellitus before, during and after various types of treatment. These results were also compared with those in alloxanized animals.

The therapeutic significance of these metabolic abnormalities were also discussed.

Metabolism of $\alpha$-keto acids in patients with diabetes mellitus.

1) The ratio of the increase of urinary pyruvate and $\alpha$-ketoglutarate in the 1st resp. 2nd hour following fructose administration to that in the fasting state was significantly higher in diabetics than in normals.

2) These abnormalities were more marked in cases complicated with hypertension or arteriosclerosis than in those without these complications.

3) Positive correlation was found between fasting blood sugar level and the ratio of urinary $\alpha$-keto acids in the 2nd hour following fructose administration.

\section{Studies on the Oxidative Metabolism of Carbohydrate in Diabetics} 2. Acetylating Activity of Diabetics

\author{
By
}

\section{Yukio SHIGETA}

From the 1st Department of Internal Medicine, Osaka University, Medical School

(Director : Prof. Dr. T. Yoshida)

1) The average acetylating activity of 62 cases with diabetes mellitus was 74.6 上10.3\% in contrast to $89.6 \pm 2.8 \%$ in normal adults.

2) Negative correlation was found between the acetylating activity and fasting blood sugar level.

3) The acetylation was found markedly decreased in juvenile patients and those with abnormal body weight.

4) Marked decrease of acetylation was found in cases complicated with hypertension or arteriosclerosis. 


\title{
糖尿病の糖質酸化機転に関する研究
}

\author{
1. 糖尿病患者の $\alpha$ ケ酸代謝
}

大阪大学医学部吉田内科 (主任 吉田常雄教授)

繁田幸男

I. 緒言

糖䐂病が体内インシュリンの絶対的乃至相対的火乏を中心とする内分泌平衙失調に起因するてとは周知の

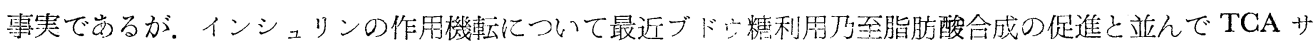

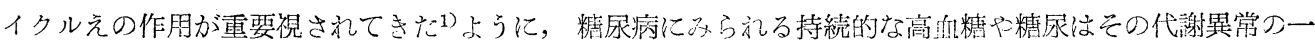

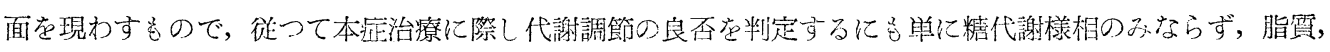
蛋白質，鉱質などの動向や共通代謝経路の様相などを导把握ずる必要がかる。

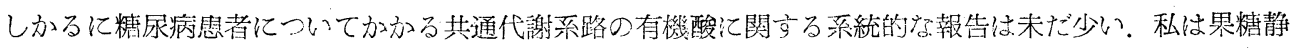
注後の尿中に排浛される焦性ブドゥ酸 (PyA) 及ご ると共に本症の病状, 合併症との関係などにつけて。比較梌討した。

\section{II，实 験 方 法}

\section{1. 被験者}

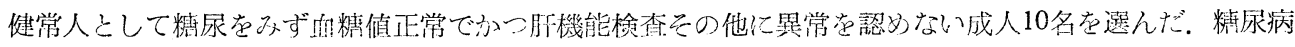

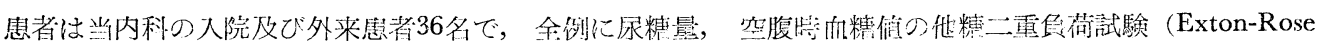



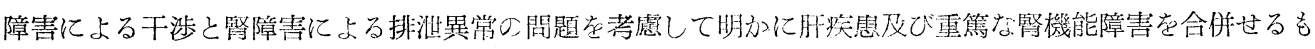
のは被験者に加えなかつた。

また患者の分類について，40才以上を老年性とし以下を若年性としたが，体型別は Broca 指数に基ずき

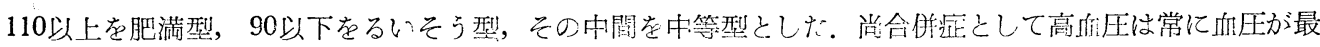

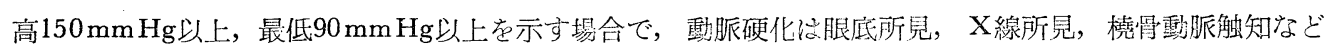
より判定し, また多発性神経炎は神経痛, 腱反射などより診断した。

\section{2. 測 定 法}

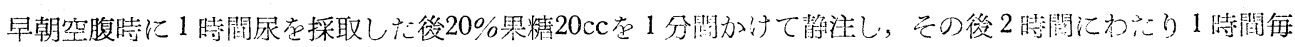
に尿を 2 回採取した。，各々の尿につにて PyA 及び KGA 排泄量を測定し，前 1 紫間尿のそれを 1 として

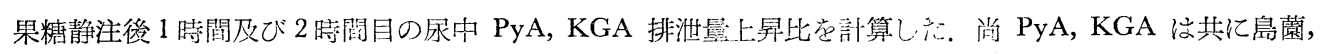

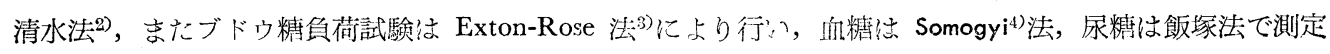
した.

\section{III. 实 験 成 績}

\section{1. 健常人及び糖尿病患者の $\alpha$ ケ酸代謝}

早朝空腹時 1 時間尿つ PyA 及び KGA 排泄量统健常人10例平均各々 $0.81 \pm 0.23 \mathrm{mg}, 1.89 \pm 0.50 \mathrm{mg}$ 亿対 し，糖尿病患者では36例平䚷各々 $1.16 \pm 0.48 \mathrm{mg}, 2.00 \pm 0.82 \mathrm{mg}$ でやや高いがての差は PyA, KGA 共統計 
学的に有意とはいえない.

$20 \%$ 果糖静注後尿中 PyA 排泔量上昇比は健常人平均 1 時闒值 $1.47 \pm 0.21 .2$ 時間值 $0.88 \pm 0.08$ であるに 対し，糖尿病患者平均 1 時間值 $2.43 \pm 0.78 .2$ 時間值 $1.48 \pm 0.42$ でいずれも患者に高值を示しての差は有意 であつた $\left(\mathrm{P}_{\gamma}<0.001\right)$ また尿中 KGA 排泄量上昇比健常人平均 1 時間值 $1.26 \pm 0.15 .2$ 時閻值 $0.89 \pm$


図)

管 1 図糖尿病患者の $\alpha$ ケト酸代謝

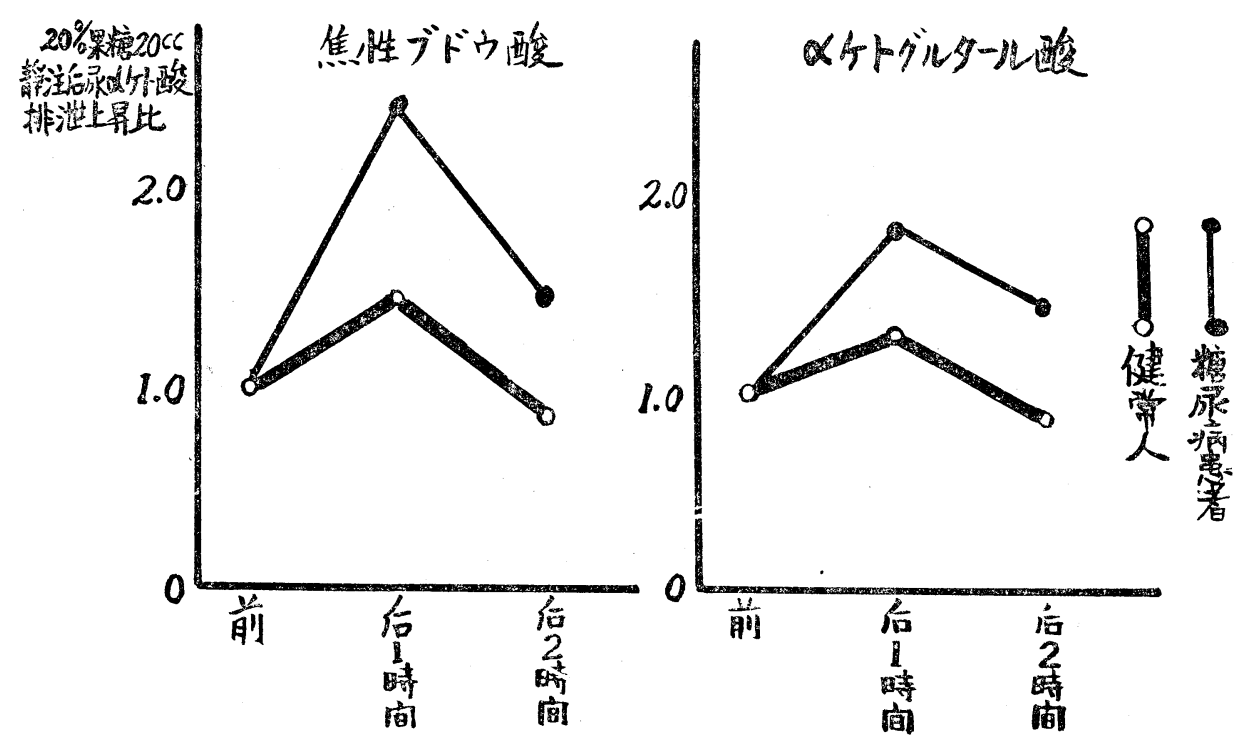

第 1 表 健常人及び糖尿病患者の $\alpha$ ケト酸代謝（その 1 ）

$(20 \%$ 果糖 $20 \mathrm{cc}$ 静注後尿中 $\alpha$ ケト酸排泄量上昇比)

\begin{tabular}{|c|c|c|c|c|c|c|c|}
\hline & \multirow{3}{*}{ 例数 } & \multicolumn{3}{|c|}{ 焦 性 ブ ドウ 酸 } & \multicolumn{3}{|c|}{$\alpha$ トケグルタール酸 } \\
\hline & & \multirow{2}{*}{$\begin{array}{l}\text { 前 } 1 \text { 時䦭 } \\
\text { 排泄量 } \\
\text { (mg) }\end{array}$} & \multicolumn{2}{|c|}{ 静注後排泄上昇比 } & \multirow{2}{*}{$\begin{array}{c}\text { 前 } 1 \text { 時間 } \\
\text { 排泄量 } \\
\text { (mg) }\end{array}$} & \multicolumn{2}{|c|}{ 静注後排泄上昇比 } \\
\hline & & & 1 時 間 & 2 時 間 & & 1 時 間 & 2 時 間 \\
\hline 健常人 & 10 & $0.81 \pm 0.23$ & $1.47 \pm 0.21$ & $0.88 \pm 0.08$ & $1.89 \pm 0.50$ & $1.26 \pm 0.15$ & $0.89 \pm 0.12$ \\
\hline 糖尿病想者 & 36 & $1.16 \pm 0.48$ & $2.43 \pm 0.78$ & $1.48 \pm 0.42$ & $2.00 \pm 0.82$ & $1.80 \pm 0.63$ & $1.49 \pm 0.43$ \\
\hline
\end{tabular}

管 2 表 健常人及び糖尿病思者の $\alpha$ ケト酸代謝（その 2 ）

$(20 \%$ 策糖 $20 \mathrm{cc}$ 静注後 2 時間目尿中 $\alpha$ ケト酸排泄量上昇比)

\begin{tabular}{|c|c|c|c|c|c|c|c|c|c|}
\hline & \multirow{2}{*}{ 総例数 } & \multicolumn{4}{|c|}{ 焦悱 ブドウ 酸 } & \multicolumn{4}{|c|}{$\alpha$ ケトグルタール酸 } \\
\hline & & $\begin{array}{l}\text { 1.0以下 } \\
\text { (例数) }\end{array}$ & $1.0 \sim 1.5$ & $1.5-2.0$ & 2.0 以上 & $\begin{array}{l}1.0 \text { 以下 } \\
\text { (例数) }\end{array}$ & $1.0 \sim 1.51$ & $1.5-2.0$ & 2.0 以上 \\
\hline 傅 䉪 人 & 10 & 9 & 1 & 0 & 0 & 8 & 2 & 0 & 0 \\
\hline 崝原病愳者 & 36 & 0 & 22 & 8 & 6 & 3 & 17 & 11 & 5 \\
\hline
\end{tabular}

尚 2 時間值を1.0以下，1.0〜 1.5，1.5〜2.0，2.0以上に分けてその症例数をみると PyA，KGA 共に健常 
人では 10 例中大多数1.0以下の中に含まれるのに比し 糖尿病患者では 36 例中 1.0 以上を示す例が大部分で 1.5 以上のものが約半数あつた。（第 2 表）

\section{2. 糖㽷病思者の年令别体型別と $\alpha$ ケ酸代謝}

本症患者を年令別に分けて $\alpha$ ケト酸代謝樣相を計算したが老年性 29 例，若年性 7 例の平均は第 3 表の如く で果糖静注後 2 時間目の尿中 KGA 排泄量上昇比は若年性の方に幾分高值を示すようであるが統計学的に有

第3 表 年令別と $\boldsymbol{\alpha}$ ケト酸代謝

\begin{tabular}{|c|c|c|c|c|c|c|c|}
\hline \multirow{2}{*}{ 年 令 別 } & \multirow{2}{*}{ 例数 } & \multicolumn{2}{|c|}{$\begin{array}{l}20 \% \text { 果糖 } 20 \mathrm{cc} \text { 静注後 } 2 \text { 時間目尿中 } \\
\alpha \text { ケ酸排泄量上昇比 }\end{array}$} & \multicolumn{3}{|c|}{ Exton-Rose Test } & \multirow{2}{*}{$\begin{array}{l}\text { 平均呞糖量 } \\
\text { (g) }\end{array}$} \\
\hline & & 焦性ブドウ酸 & $\alpha$ ケトグルタール酸 & 前 $(\mathrm{mg} / \mathrm{dl})$ & 30 分 & 60 分 & \\
\hline 若 年 性 & 7 & $1.60 \pm 0.46$ & $1.57 \pm 0.38$ & $214 \pm 86$ & $303 \pm 104$ & $393 \pm 114$ & 70 \\
\hline 老 年 性 & 29 & $1.45 \pm 0.40$ & $1.47 \pm 0.44$ & $160 \pm 48$ & $252 \pm 43$ & $330 \pm 52$ & 45 \\
\hline
\end{tabular}

第 4 表 体型別と $\alpha$ ケト酸代謝

\begin{tabular}{|c|c|c|c|c|c|c|c|}
\hline \multirow{2}{*}{ 体 型 別 } & \multirow{2}{*}{ 例数 } & \multicolumn{2}{|c|}{$\begin{array}{l}20 \% \text { 果糖 } 20 \mathrm{cc} \text { 静注後 } 2 \text { 時間目尿中 } \\
\alpha \zeta \text { 酸排泄量上昇比 }\end{array}$} & \multicolumn{3}{|c|}{ Exton-Rose Test } & \multirow{2}{*}{$\begin{array}{l}\text { 平 均 } \\
\text { 尿糖量 } \\
(\mathrm{g})\end{array}$} \\
\hline & & 焦性ブドウ酸 & $\alpha$ $\alpha$ トグルタール酸 & 前 $(\mathrm{mg} / \mathrm{dl})$ & 30 分 & 60 分 & \\
\hline 肥 满 型 & 14 & $1.53 \pm 0.53$ & $1.41 \pm 0.49$ & $150 \pm 35$ & $239 \pm 41$ & $312 \pm 56$ & 29 \\
\hline 中 等 型 & 6 & $1.53 \pm 0.39$ & $1.52 \pm 0.42$ & $160 \pm 41$ & $230 \pm 54$ & $364 \pm 51$ & 59 \\
\hline るいそう型 & 16 & $1.43 \pm 0.33$ & $1.57 \pm 0.36$ & $185 \pm 63$ & $275 \pm 89$ & $360 \pm 97$ & 70 \\
\hline
\end{tabular}

意な差は見出し得なかつた。また体型別では肥満型14例，中等型 6 例，るいそう型16例刀平均値は第 4 表の 如くで，KGAに扔いてるいそう型〉中等型〉肥満型の順に高值であつたが有意の差とは断定し得ない。

\section{3. 合併症と $\alpha$ ケト酸代謝}

糖尿病患者の合併症と $\alpha$ ケト酸代謝棁相の関連をみると先づ高血压を合併するもの11例，合併しないもの 25例の平均は第 5 表の如くで果糖静注後 2 時間目の尿中 PyA, KGA 排泄量上昇比は其に前者に高值を示し,

第 5 表 合欮症と $\alpha$ ケト酸代謝

\begin{tabular}{|c|c|c|c|c|c|c|c|c|}
\hline \multirow{2}{*}{\multicolumn{2}{|c|}{ 合併症 }} & \multirow{2}{*}{ 例数 } & \multicolumn{2}{|c|}{$\begin{array}{l}20 \% \text { 果䊀 } 20 \mathrm{cc} \text { 静注後 } 2 \text { 時間目尿中 } \\
\alpha \text { ケト酸排泄量上秋比 }\end{array}$} & \multicolumn{3}{|c|}{ Exton-Rose Test } & \multirow{2}{*}{$\begin{array}{l}\text { 平均 } \\
\text { 尿糖量 } \\
\text { (g) }\end{array}$} \\
\hline & & & 焦性ブドウ酸 & $\alpha$ 年トグルタール酸 & 前 $(\mathrm{mg} / \mathrm{dl})$ & 30 分 & 60 分 & \\
\hline \multirow{2}{*}{$\begin{array}{l}\text { 高 } \\
\text { 臭 } \\
\text { 压 }\end{array}$} & 有 & 11 & $1.65 \pm 0.46$ & $1.58 \pm 0.44$ & $163 \pm 46$ & $254 \pm 52$ & $339 \pm 52$ & 50 \\
\hline & 無 & 25 & $1.41 \pm 0.39$ & $1.46 \pm 0.41$ & $165 \pm 49$ & $260 \pm 47$ & $343 \pm 58$ & 49 \\
\hline 動硬 & 有 & 15 & $1.53 \pm 0.45$ & $1.70 \pm 0.51$ & $171 \pm 54$ & $260 \pm 55$ & $351 \pm 62$ & 49 \\
\hline 脈化 & 無 & 21 & $1.44 \pm 0.40$ & $1.35 \pm 0.36$ & $159 \pm 43$ & $257 \pm 46$ & $331 \pm 53$ & 50 \\
\hline \multirow{2}{*}{$\begin{array}{l}\text { 多神 } \\
\text { 永経 } \\
\text { 性炎 }\end{array}$} & 有 & 16 & $1.49 \pm 0.42$ & $1.48 \pm 0.41$ & $170 \pm 51$ & $269 \pm 56$ & $344 \pm 57$ & 51 \\
\hline & 無 & 20 & $1.49 \pm 0.41$ & $1.50 \pm 0.44$ & $160 \pm 44$ & $249 \pm 41$ & $341 \pm 56$ & 48 \\
\hline
\end{tabular}

動脈硬化についても合併者15例，非合併者21例の平均值は PyA，KGA 共に合併者に高く，特に高血圧合併 症つ PyA, 動脈硬化症の KGA 值は統計学的に有意の高值を示した（共にPr $<0.001$ ).しかし多発性神経炎 は合伤者16例と非合併者20例の䦭に平均值の上では何等の差も認められなかつた。

\section{4. $\alpha$ ケト酸代謝と空腹時血糖值 Exton-Rose Test1 1時間血糖値との相関}

果糖静注後 2 時間目の厡中 PỵA 排泄量上昇比と空腹時血糖值との間の相関总みると第 2 図に示す如く血 
第 2 図空腹時血糖値と焦跣ブドウ酸代謝との相関

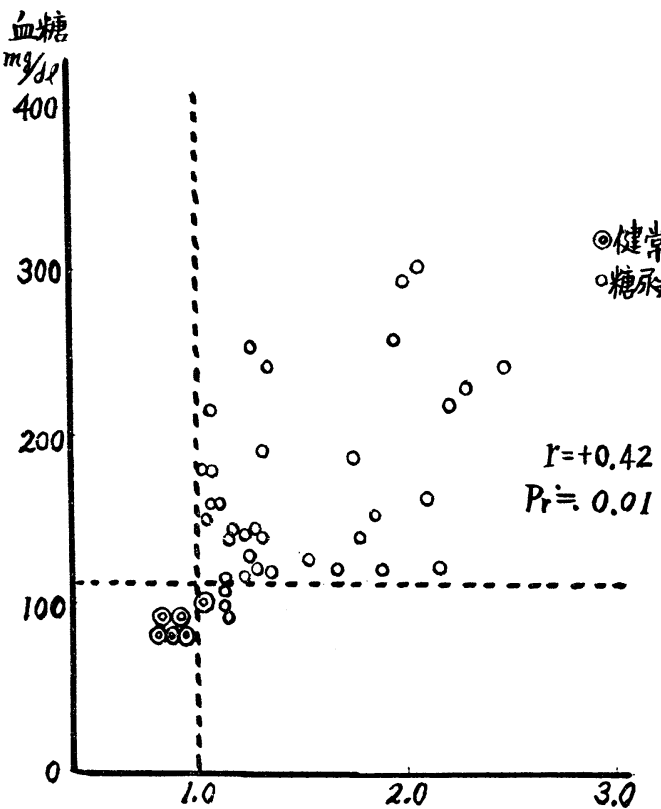

$20 \%$ 果糖 $20 \mathrm{cc}$ 静注後 2 時間目尿 PyA 排泄上昇比 第3 図 Exton-Rose Test（1 時間值） と焦性ブドゥ酸代謝との関係

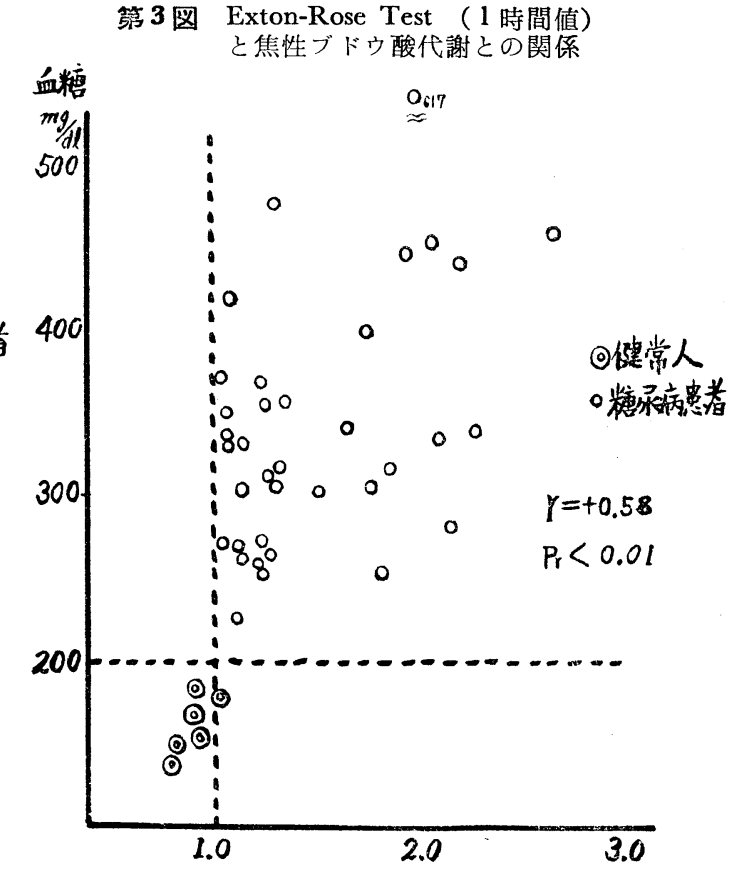

$20 \%$ 果糖 $20 \mathrm{cc}$ 静注後原中 PyA 排泄上昇比 ( 2 時間目)
第4図空腹時血粭値と $\alpha$ ケトグルタール酸 代謝との相関

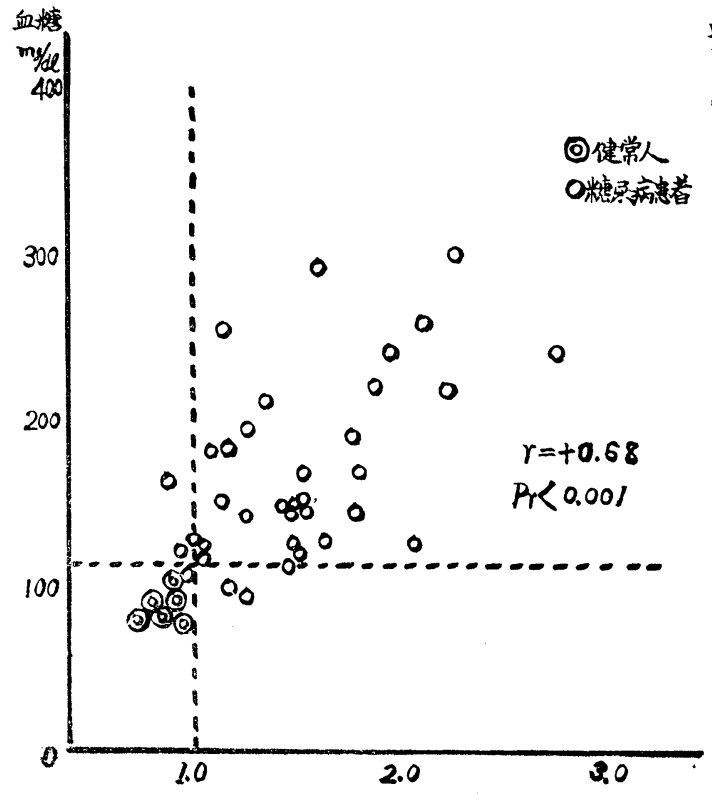

$20 \%$ 果糖 $20 \mathrm{cc}$ 静注後 2 時間目 K G A 排泄上昇比
管 5 図 Exton-Rose Test（1 時間值）

と矢トグルタール酸代謝との相関

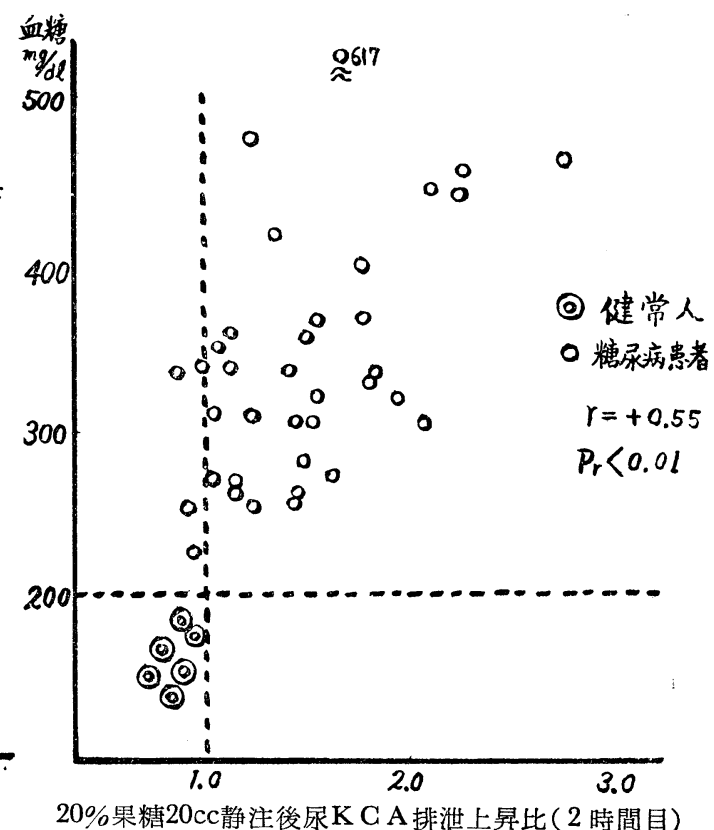


糖值の高いもの程 PyA 上昇比は高度で順相関があり $(\mathrm{r}=+0.42, \operatorname{Pr}<0.01)$, またPyA 上昇比と Exton-





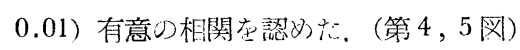

\section{IV. 総括並びに考按}

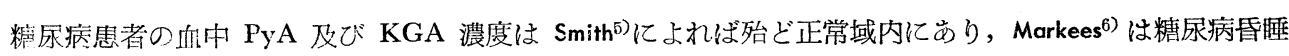
の場合に始めて著明に上昇すると述へているが，ての際血中 PyA 濃度を左右する二つの因子が考えられる。


ブドウ糖活性化障害のだめのPyA 生成娍少で, 他の一つは PyA 酸化障害による PyA 畜積堌大で㟧る。

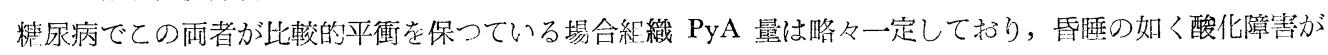
高度となるとPyA 量の增大をみるものと考えられる。事実 Klein ${ }^{8)}$, Amatuzio ${ }^{9)}$ ，Shrifter ${ }^{10)}$ 等多数の研究者 によつて糖尿病患者にブドゥ糖を経口的乃至静注負荷した際, 健常人に比し血中 PyA 濃度上昇が遅れて現 われ，解糖の障害山るてとが明かにされている。

そこで私はブドウ糖の代りに果桾を用いて糖尿病患者のPyA, KGA 酸化の動向を検索した。沢田 ${ }^{11)}$, 榎 12)，向山13)等は20\%ブドゥ糖 $20 \mathrm{cc}$ を健常成人に静注すると血液や尿中の乳酸, PyA, KGAの堌加は少く, 20\%果糖20cc静注ではてれら酸の著增するを認めたが，糖尿病に扔いてグルコキナーゼ活性の著しい障害に

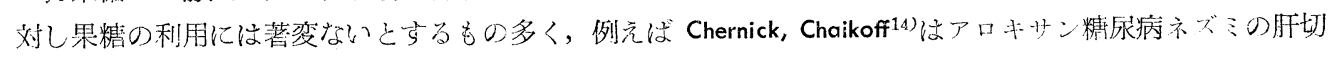

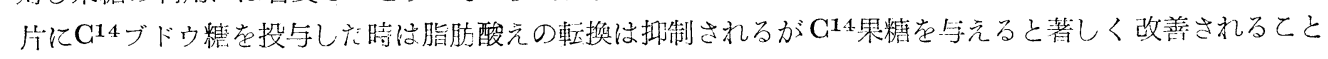

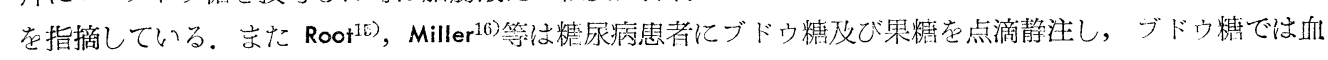

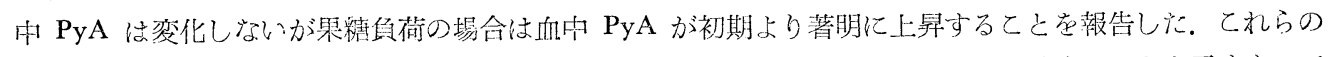

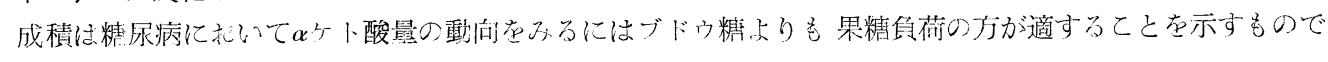
ある。

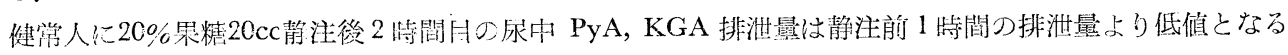

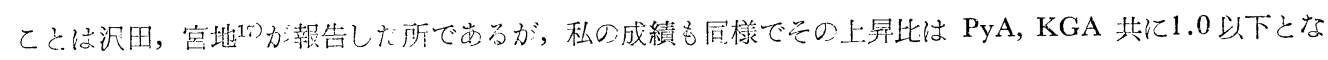

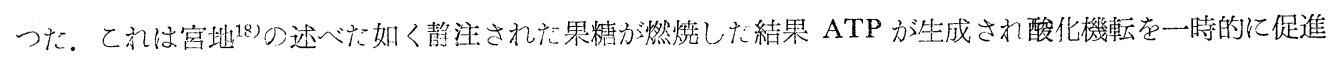
するるのと思われる。


比の著明な増大を来したが，乙れは明が本症に就ける PyA 並び KGA に酸化障害に基ずくものと考えら れる。

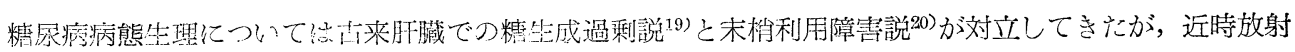

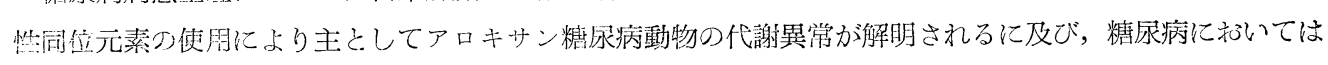
組織刀糖利用能乃至酸化障害の存在を説明する成績が相次いで現われ，糖利用障害説が益々積極的に支持さ れるようになつてきた。

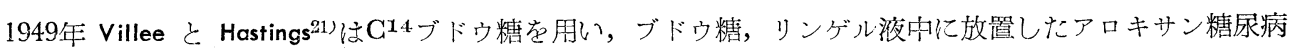
ネズミ横隔膜つ糖原及び $\mathrm{CO}_{2}$ を追跡し，対照に比しいずれも著明に減少するととを認め，Glock ${ }^{222}$, Bloom ${ }^{23)}$,

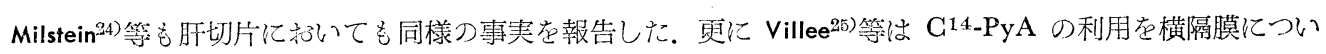
て in vitro で检討し, 糖尿病群でCo 2 光の酸化が減少しているという結果堂得た。 また Navazio, Siliprandi

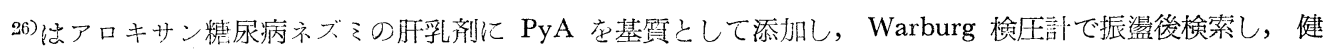
常群に比し PyA の诚少结軽度でかつクエン酸尘成が強く阻害されているととを明かにした，以上の事実は 糖尿病に PyA の利用乃至酸化障害の存するてとを in vitro で証明したものであるが，in vivoでも既に 
Flock ${ }^{27)}$ は糖尿病犬に PyA 負荷を行つた際, 血中 PyA 及び乳酸の対照に比し高值を持続するを報告して扔 り PyA 而性の低下がうかが党る。

しかし本症ではブドウ糖の利用障害があるため患者に扑いて

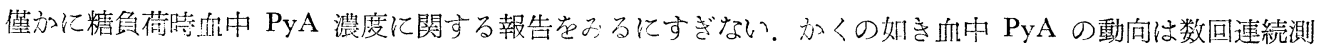
定するのでなければ $\alpha$ ケト酸代謝様相を明かにし得ないうらみが觉る。私の方法では比較的簡単に $\alpha$ ケト酸

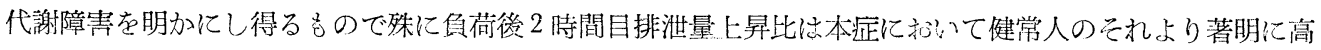
い. また㭧者の空腹時血糖值並びそ Exton-Rose Test 1 特間血糖值と上記 $\alpha$ ケ酸代謝との間に一定の相関 があり，重症なるの程糖質酸化機転障害が著明であつたが必ずしも平行しないものき岕り，從つて本症の病 状, 治療効果判定には従来の血糖值, 尿楉量, 尿アセトン体の他にかふるる果糖負荷試験を行ない体内糖利用 能乃至酸化機転をもうかがう必要が西ると思われる。

\section{V. 結 論}

健常人 10 例及び糖尿病患者 36 例に $20 \%$ 果梼 $20 \mathrm{cc}$ 静注後尿中 PyA 並びに KGA 排泄量上昇比を検索し，次 の如总結調を得 $た$.

（1）糖尿病患者に扔いては健常人に比し果糖静注後 1 時間及び 2 時間目の尿中 PyA, KGA 排泄量上昇比 はいずれも著しく堌大し，PyA 及び KGA の酸化障害と考えられる成績を得て。

(2) 果糖静注後 2 時闑目尿中 PyA, KGA 排泄量上昇比は 空腹時血糖值並びに Exton-Rose Test 1 時間 血桾值と概ね平行し重症なきの程高値を示した。

(3) 年令別，体型別でば特に有意な差を諗めなかつた。

（4）合併症については高血圧及び動脈硬化を合併せるものに $\alpha$ ケ酸排泄量上昇比念高值を示しふが，多 発性神経炎合併者にはか汃る事実を認好なかつた。

（5）上記果糖負荷試験は血糖，尿糖，尿アセトン体等と並んで本症の病状，沿療效果判定に用いるととが 望京しい.

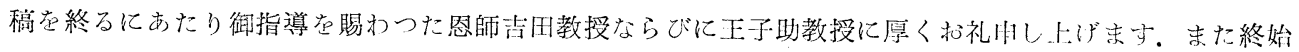
御踈撻下さつた和旧講師に深謝すると共に御協力戴いた海野学士等の諸氏に感謝致します。

\section{主 要 文 献}

1) Stadie, W.C. : Amer. J. Med. 19, 257 (1955).

3) Exton, W.G. : Amer. J. Clin. Path. 4, 381 (1934). (1945). $\quad$ 5) Smith, M.J.H. : Lancet. 1, 268 (1955) 81,1145 (1951).

7) Cori, C.F. : Harvey dect. 41, 253 (1945). 145, 35 (1943).

9) Amatuzio, D.S. : J. Clin. Invest. 31, 751 (1953).

Int. Med. 98, 28 (1956)

11) 沢田: 福岡医学杂倠誌, 42, 367 (1951).

13) 向山：日新医学，40，345 (1953) 40, 108 (1953) 15) Root, H.F. : Amer. J. Med. Soc. 211, 189 (1946). 188, 389 (1951).

17) 沢田，宮地：最新医学，8，83 (1953).

19) Noorden, C. : Die Zuckerkrankheit. Berlin. Springer (1928). 地 ・ビタミン, $10,253(1956)$.

20) Naunyn, B. : Der Diabetes Mellitus. Wien. Hölder (1899). 21) Villee, C.A. : J. Biol Chem. 179, 673 (1949). 22) Glock, G.E. : Biochem. J. 63, 520 (1956).

23) Bloom, B. : J. Biol. Chem. 215, 467 (1955).

24) Milstein, S.W. : Proc. Soc. Exp. Biol. Med. 92, 632 (1956).

J. Biol. Chem. 195, 287 (1952).

J. Biol. Chem. 134, 282 (1940).
26) Navazio, F. : Enzymologia 17, 225 (1955).

25) Villee, C.A. : 